\title{
New year's greetings 2018 from the Journal of Plant Research
}

\author{
Kouki Hikosaka ${ }^{1}$
}

Published online: 3 January 2018

(c) The Botanical Society of Japan and Springer Japan KK, part of Springer Nature 2018

As we begin a new year, I am very pleased to announce that this issue starts with a JPR symposium entitled "Semiin-vivo developmental biology" under the supervision of Drs. Yuki Kondo and Shigeo Sugano. This JPR symposium focuses on recent attempts to analyze developmental processes and biological phenomena with the use of unique assays. Recent advances in studies for developmental processes of vascular systems (Blob et al. 2018; Kondo 2018; Oda 2018), grafting (Nanda and Melnyk 2018), cell-to-cell communication during plant fertilization (Kanaoka 2018), and circadian clock in plants (Muranaka and Oyama 2018) are reviewed. In a future issue this year, another JPR Symposium entitled "Floral development: re-evaluation of its importance" will be published under the supervision of Drs. Akitoshi Iwamoto and Kester Bull-Hereñu.

JPR has established a new policy for research data. We strongly encourage authors to ensure that data and materials integral to the paper are available to readers in a form that allows for verification and replication of the results in the paper. In particular, the DNA and RNA sequences, nextgeneration sequencing data, genetic polymorphisms, macromolecular structure, and microarray data are required to be deposited in publicly available repositories (where available and appropriate) or presented in the main manuscript or additional supporting files whenever possible. See the Instructions to Authors for detail.

We welcome new Editorial Board members who begin their 4-year terms in January 2018: Drs. Peter Comes, Harald Schneider, Hidetoshi Sakayama, Yudai Okuyama, Daniele Cicuzza, Masaki Shimamura, Gyung-Tae Kim, Munetaka
Sugiyama, John Bowman, Hidehiro Fukaki, Attila Kereszt, Neung Teaumroong, Jeong Sheop Shin, Noriaki Tanabe, Kenichi Tsuda, and Hironori Fujita.

We thank Editorial Board members who rotated off the Board: Drs. Noriaki Murakami, Richard Ree, Niels Anten, Jun Nishihiro, Sachihiro Matsunaga, Makoto Kusaba, Shinichiro Sawa, Antony Bacic, Michael Cohen, and Takeshi Obayashi.

We wish you a Very Happy New Year, and we welcome submissions of excellent articles in 2018.

Kouki Hikosaka

Editor-in-Chief, Journal of Plant Research

\section{References}

Blob B, Heo JO, Helariutta Y (2018) Phloem differentiation: an integrative model for cell specification. J Plant Res. https://doi. org/10.1007/s10265-017-0999-0

Kanaoka MM (2018) Cell-cell communications and molecular mechanism in plant sexual reproduction. J Plant Res. https://doi. org/10.1007/s10265-017-0997-2

Kondo Y (2018) Reconstitutive approach for investigating plant vascular development. J Plant Res. https://doi.org/10.1007/ s10265-017-0998-1

Muranaka T, Oyama T (2018) Monitoring circadian rhythms of individual cells in plants. J Plant Res. https://doi.org/10.1007/ s10265-017-1001-x

Nanda AK, Melnyk CW (2018) The role of plant hormones during grafting. J Plant Res. https://doi.org/10.1007/s10265-017-0994-5

Oda Y (2018) Emerging roles of cortical microtubule-membrane interactions. J Plant Res. https://doi.org/10.1007/s10265-017-0995-4

Kouki Hikosaka

hikosaka@m.tohoku.ac.jp

1 Graduate School of Life Sciences, Tohoku University, Aoba, Sendai 980-8578, Japan 